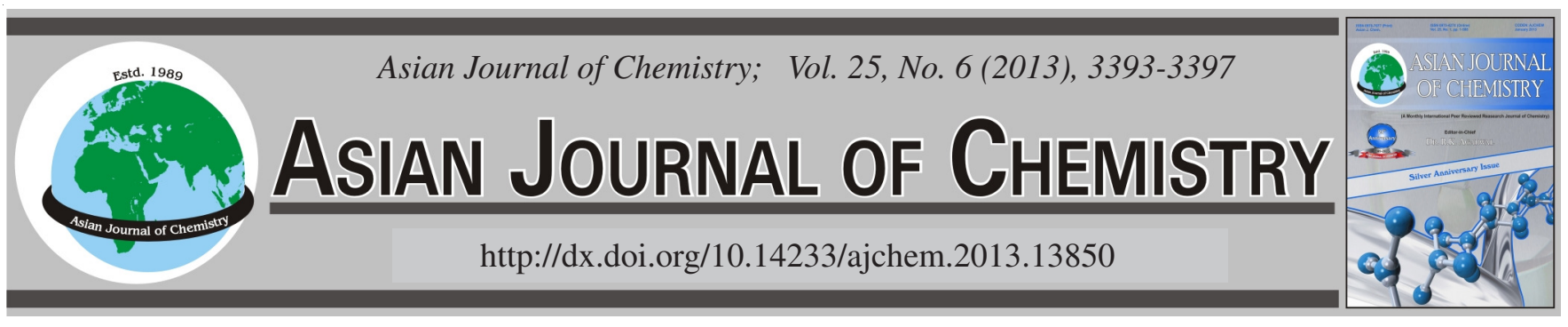

\title{
Determination of Se(IV) in Pharmaceuticals by Using Different Operating Modes of Pulse Anodic Stripping Voltammetric Analysis with Methylene Blue-Nafion Modified Gold Electrode
}

\author{
Abdul Aziz Ramadan*, Hasna Mandil and Amer Ozoun
}

Department of Chemistry, Faculty of Sciences, Aleppo University, Aleppo, Syria

*Corresponding authors: Fax: +963 21 2633136; E-mail: dramadan@scs-net.org; mandil@ scs-net.org

\begin{abstract}
Determination of selenium(IV) in Syrian pharmaceuticals with a methylene blue-nafion modified gold electrode by using different operating modes of pulse anodic stripping voltammetry : with constant amplitude of negative (PASVNP) or positive (PASVPP) polarity, imposed pulses of linearly increasing amplitude (PASVLIA) and differential sampling on successive pulses $(\Delta \mathrm{I} / \Delta \mathrm{t})$ was applied. Selenium(IV) was determined in an aqueous $\mathrm{HClO}_{4}$ medium $(1 \mathrm{M})$ at an accumulation potential of $-240 \mathrm{mV}$ and an accumulation time of $300 \mathrm{~s}$. The potential was scanned from 0.0 to $1250 \mathrm{mV}$ using auto-scan facility. The peak potential was measured at 1000-1010, 1030-1040, 1130-1140 and $1030-1060 \mathrm{mV}$ and the calibration curve for Se(IV) under optimized conditions was linear in the ranges 7.896-78.96, 23.688-118.44, 23.688-118.44 and 0.7896-78.96 $\mathrm{ng} \mathrm{mL}^{-1}$ for operating modes PASVNP, PASVPP, PASVLIA and $\Delta \mathrm{I} / \Delta \mathrm{t}$, respectively. RSD was less than $5 \%$. The methods were applied to the determination of Se(IV) in Syrian pharmaceuticals with high sensitivity and accuracy. The results obtained by pulse anodic stripping voltammetry methods were validated by atomic absorption spectroscopy with hydride generation.
\end{abstract}

Key Words: Selenium, Pharmaceuticals, Different operating modes of pulse anodic stripping voltammetry.

\section{INTRODUCTION}

The high tendency of 5-nitropiazselenol for self-accumulation on thin mercury film electrode was used innovatively for determination of Se(IV) in natural waters. 5-Nitropiazselenol was formed by reaction between Se(IV) and 4-nitro-1,2-phenylenediamine in acidic solution and self-accumulation process was carried out directly from reaction media. The adsorbed 5-nitropiazselenol was stripped in $\mathrm{HCl}$ solution by differential pulse cathodic potential scan. Detection limit of this method is $0.06 \mathrm{ng} \mathrm{mL}^{-1}$. This method was applied for determination of $\mathrm{Se}(\mathrm{IV})$ in natural waters collected from some internationally registrated lagoons south of Caspian $\mathrm{Sea}^{1}$.

Differential pulse cathodic stripping voltammetric determination of selenium from pharmaceutical products was applied. The peak potential is $-0.545 \mathrm{~V} v s$. $\mathrm{Ag} / \mathrm{AgCl}$ and the calibration curve is linear up to $0.125 \mathrm{ng} \mathrm{mL}^{-1}$, but selenium was determined in the range 8 to $64 \mathrm{ng} \mathrm{mL}^{-1}$ in pharmaceutical products used the calibration curve ${ }^{2}$.

A simple and fast cathodic stripping voltammetric procedure for determination of trace quantity of Se(IV) in natural samples containing high concentrations of surfactants and humic substances was developed. The procedure exploiting selenium accumulation ffrom sample solution spiked with 0.1 mol L ${ }^{-1} \mathrm{HClO}_{4}$ and $\left.4 \times 10^{-4} \mathrm{~mol} \mathrm{~L}^{-1} \mathrm{Cu}\left(\mathrm{NO}_{3}\right)_{2}\right\}$ as $\mathrm{Cu}_{2} \mathrm{Se}$ was employed as the initial method. The deposited $\mathrm{Cu}_{2} \mathrm{Se}$ was stripped by differential pulse cathodic potential scan. The method was tested on synthetic samples spiked with surfactants and humic substances. The calibration graph for Se(IV) under optimized conditions following the accumulation of $30 \mathrm{~s}$ was linear in the range from $2 \times 10^{-9}$ to $2 \times 10^{-7} \mathrm{~mol} \mathrm{~L}^{-1}$ and was found to obey the equation $y=0.74 x-0.61$, where $y$ and $x$ are the peak current (nA) and $\mathrm{Se}(\mathrm{IV})$ concentration (nmol $\mathrm{L}^{-1}$ ), respectively. The linear correlation coefficient was $\mathrm{r}=$ 0.9993. The relative standard deviation for determination of $\mathrm{Se}(\mathrm{IV})$ at the concentration of $1 \times 10^{-8} \mathrm{~mol} \mathrm{~L}^{-1}$ was $3.7 \%(\mathrm{n}=5)^{3}$.

The suitability of a carbon paste electrode coupled with differential pulse voltammetry (DPV) has been investigated for the determination of Se(IV) after complexation with 2,3diaminonaphthalene (2,3-DAN). A decrease of oxidation current of 2,3-diaminonaphthalene was observed due to the formation of a complex of 2,3-diaminonaphthalene with $\mathrm{Se}(\mathrm{IV})$. The calibration plots were linear in the range from 1 to $10 \mu \mathrm{g} \mathrm{\textrm {L } ^ { - 1 }}$ with $\mathrm{r}=0.998$ and 10 to $100 \mu \mathrm{g} \mathrm{L}^{-1}$ with $\mathrm{r}=0.998$. The relative standard deviation for five replicate analyses of $10 \mu \mathrm{g} / \mathrm{L}$ of selenium was $2.5 \%$. The limit of detection was 0.7 $\mu \mathrm{g} \mathrm{L}{ }^{-1}$. The voltammetric method was used for the determination of Se(IV) in tap water and pharmaceutical preparation. The results obtained by DPV method were validated by inductively coupled plasma optical emission spectroscopy (ICP-OES) ${ }^{4}$. 
The behaviour of selenium(IV) at a mercury-film electrode previously modified with copper was studied by cathodic stripping voltammetry using an automatic system for replacing solutions without opening the circuit. The detection limit for selenium(IV) was found to be $40 \mathrm{ng} \mathrm{L}^{-1}\left(5.0 \times 10^{-10} \mathrm{M}\right)$ at an electrolysis time of $10 \mathrm{~min}^{5}$.

A simple micellar liquid chromatographic technique for the determination of selenium(IV) in pharmaceutical products (multi-vitamin tablets, syrups) and animal premixes after pre-column derivatization with 2,3-diaminonaphthalene was developed and validated. Hypersil ODS column, $10 \%$ (v/v) 1-butanol in $0.05 \mathrm{M}$ sodium dodecyl sulfate as the mobile phase and UV detection at $378 \mathrm{~nm}$ and were used. The retention time was about $8 \mathrm{~min}$. In the course of the validation study, the specificity of the method was demonstrated. Linearity was established in the range $0.33-3.3 \mu \mathrm{g} \mathrm{mL}^{-1}$ of selenium(IV) content. The limits of detection and quantitation were 0.1 and $0.3 \mu \mathrm{g} \mathrm{mL} \mathrm{m}^{-1}$, respectively. The method showed excellent accuracy $(100.04 \%)$. Precision (repeatability) gave a relative standard deviation less than $1 \%$.

A hydride generation method for the determination of

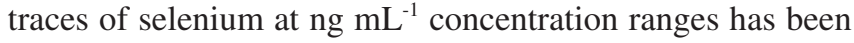
introduced using a solid mixture of tartaric acid and sodium tetrahydroborate. Atomic absorption spectrometry has been used as the detection system. Several parameters such as the ratio of tartaric acid to sodium tetrahydroborate, type and amount of acid and the reaction temperature were optimized by using $640 \mathrm{ng} \mathrm{mL}^{-1}$ of Se(IV) standard solution. The calibration curve was linear from 20 to $1200 \mathrm{ng} \mathrm{mL}^{-1}$. The relative standard deviation (\% R.S.D.) of the determination was $1.93 \%$ and the detection limit was $10.6 \mathrm{ng} \mathrm{mL}^{-1}$. The reliability of the method was checked using different types of environmental samples, such as several types of water, a sample of soil and also in a kind of calcium phosphate sample by standard additions method ${ }^{7}$.

Differential pulse anodic stripping voltammetric (DPASV) determination of selenium(IV) using a vitamin E-nafion modified gold electrode ( $\mathrm{V}_{\mathrm{E}} \mathrm{NMGE}$ ) has been studied. Selenium(IV) was determined in an aqueous $\mathrm{HClO}_{4}$ medium of $\mathrm{pH} 1.10$ at an accumulation potential of $-240 \mathrm{mV}$ and an accumulation time of $300 \mathrm{~s}$. Under the optimum conditions, liner calibration graph, $I_{p}=f\left(C_{\mathrm{Se}^{4+}}\right)$, was obtained in the concentration ranges of $5 \times 10^{-8}$ to $1 \times 10^{-5} \mathrm{~mol} \mathrm{~L}^{-1}$ with relative standard deviations (RSD) $\leq 4.5 \%$. This method shows that, the results for the determination of $\mathrm{Se}$ (IV) using $\mathrm{V}_{\mathrm{E}} \mathrm{NMGE}$ were more sensitive and accurate than that obtained using bare gold electrode; the sensitivity was increased about 200 times $^{8}$.

Differential pulse anodic stripping voltammetric (DPASV) determination of selenium(IV) using a methylene blue -nafion modified gold electrode (MBNMGE) has been studied. Selenium(IV) was determined in an aqueous $\mathrm{HClO}_{4}$ medium $(1.0 \mathrm{M})$ at an accumulation potential of $-240 \mathrm{mV}$ and an accumulation time of $300 \mathrm{~s}$. The potential was then scanned from 0.0 to $1250 \mathrm{mV}$ by differential pulse anodic stripping voltammetry using the auto-scan facility. The peak height was measured at 1030-1060 mV. The calibration graph for Se(IV) under optimized conditions was linear in the range from $1 \times 10^{-8}$ to $1 \times 10^{-6} \mathrm{~mol} \mathrm{~L}^{-1}$ and was found to obey the equation $y=11.50 x+0.003$, where $y$ and $x$ are the peak current $(\mu \mathrm{A})$ and $\mathrm{Se}(\mathrm{IV})$ concentration $\left(\mu \mathrm{mol} \mathrm{L} \mathrm{L}^{-1}\right.$ or $\left.\mu \mathrm{M}\right)$, respectively. The coefficient of determination was $\mathrm{R}^{2}=0.999$. The relative standard deviations (RSD) for determination of Se(IV) at the concentration of $1 \times 10^{-8} \mathrm{~mol} \mathrm{~L}^{-1}$ was $4.2 \%(\mathrm{n}=5)$. The detection limit was $5.0 \times 10^{-9} \mathrm{~mol} \mathrm{~L}^{-1}$. This method shows that, the results for the determination of Se(IV) using MBNMGE were more sensitive and accurate than that obtained using vitamin Enafion modified gold electrode ( $\left.\mathrm{V}_{\mathrm{E}} \mathrm{NMGE}\right)$ about 5 times and about 1000 times using bare gold electrode ${ }^{8}$.

\section{EXPERIMENTAL}

A Metrohm 797 VA processor, A Metrohm 797 VA stand with a multi-mode electrode (MME), an auxiliary platinum electrode, a reference electrode $(\mathrm{Ag} / \mathrm{AgCl})$, the three-electrode cell and a polarograghic analyser, model PRG-5 (Tacussel), for using different operating modes of pulse anodic stripping voltammetry (PASV): with constant amplitude of negative (PASVNP) or positive (PASVPP) polarity, imposed pulses of linearly increasing amplitude (PASVLIA) and imposed pulses of linearly increasing amplitude, with current measurement by means of differential sampling on successive pulses $(\Delta \mathrm{I} / \Delta \mathrm{t})$ were applied. A programmer model POLARMAX-78 and a recorder model ECOSRIPT (Tacussel) were also used. A rotating disk gold electrode (RDGE) model DI-65-14 (Tacussel) was used as a working modified gold electrode ${ }^{8}$. The reference electrode was $\mathrm{Ag} / \mathrm{AgCl}$ model BJC. The solution was stirred with a rotating electrode and was kept in a thermostat at $25^{\circ} \mathrm{C}$. The diluter pipette model DIP-1 (Shimadzu), having $100 \mu \mathrm{L}$ sample syringe and five continuously adjustable pipettes covering a volume range from 20 to $5000 \mu \mathrm{L}$ (model PIPTMAN $\mathrm{P}$, GILSON), were used for preparation of the experimental solutions.

Nafion perfluorinated ion-exchange resin (5\%) was purchased from Aldrich. Methylene blue, $\mathrm{H}_{2} \mathrm{SeO}_{3}$ and all other reagents were of analytical grade from Merck. A stock solution (a) $1 \times 10^{-4} \mathrm{~mol} \mathrm{~L}^{-1}$ and stock solution (b) $1 \times 10^{-6} \mathrm{~mol} \mathrm{~L}^{-1}$ of $\mathrm{Se}(\mathrm{IV})$ were prepared in $1.0 \mathrm{M} \mathrm{HClO}_{4}$. A working solutions for voltammetric investigations were prepared by dilution of the stock solutions (a or b) using 1.0 $\mathrm{M} \mathrm{HClO}_{4}$.

A commercial formulations (tablet) were used for the analysis of Se(IV) by using different operating modes of PASV: with PASVNP, PASVPP, PASVLIA and $\Delta \mathrm{I} / \Delta \mathrm{t}$ methods. The pharmaceutical formulations were used as the follows: Cenyite Silver, Pharmasyr Co.-Damascus-Syria, Each tablet contains: $20 \mu \mathrm{g}$ Selenium; Cenvite, Pharmasyr Co.-Damascus- Syria, Each tablet contains: $25 \mu \mathrm{g}$ Selenium; Ophtavite, Medipharm for Pharmaceutical Industries -Damascus-Syria, License No.

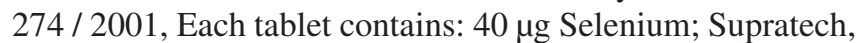
MPI-Damascus-Syria, Licensed by: Roche Consumer HelthSwizerland, Each tablet contains: $55 \mu$ g Selenium; Adavit Silver, Adamco Co.-Damascus-Syria, each tablet contains: 105 $\mu \mathrm{g}$ selenium. Three tablets of each studied pharmaceutical formulations were placed in the crucible of platinum, burning it until the flame was ended, then crushed and dissolved with $10 \mathrm{~mL}$ nitric acid $(65 \%)$. After that, it was heated until the drought, then dissolved with a solution of $1 \mathrm{M} \mathrm{HClO}_{4}$ and filtered over a $100 \mathrm{~mL}$ flask and diluting to $100 \mathrm{~mL}$ with same 
solution of $\mathrm{HClO}_{4}$. Five stock solutions of pharmaceuticals i.e., cenyite silver, cenvite, ophtavite, supratech and adavit silver, which content: 600, 750, 1200, 1650 and $3150 \mathrm{ng} \mathrm{mL}^{-1}$ of Se(IV), respectively. Working solutions of pharmaceuticals were prepared by diluting: 4.167, 3.333, 2.084, 1.515 and 0.794 $\mathrm{mL}$ of stock solutions respectively to $100 \mathrm{~mL}$ with $1 \mathrm{M} \mathrm{HClO}_{4}$ (each one content $25 \mathrm{ng} \mathrm{mL}^{-1}$ selenium). Working standard additions solutions of pharmaceuticals were prepared as the follows: same mentioned volumes of stock solutions of pharmaceuticals with $0.100,0.200,0.300,0.500,0.750$ and 1.000 $\mathrm{mL}$ from stock solution (b) of selenium and diluting to 100 $\mathrm{mL}$ with $1.0 \mathrm{M} \mathrm{HClO}_{4}$; each one content $25 \mathrm{ng} \mathrm{mL}^{-1}$ selenium (from pharmaceutical formulations) with 7.896, 15.792, $23.688,39.48,59.22$ and $78.96 \mathrm{ng} \mathrm{mL}^{-1}$ selenium from standard additions solutions of $\mathrm{Se}(\mathrm{IV})$, respectively.

A $10 \mathrm{~mL}$ volume of a solution containing an appropriate concentration of selenium (from working solutions of selenium or working solutions of pharmaceuticals or working standard additions solutions of pharmaceuticals) was transferred into an electrochemical cell. The accumulation potential $(-240 \mathrm{mV})$ was applied to the modified electrode for a certain time. The potential was then scanned from 0.0 to $1250 \mathrm{mV}$ with the autoscan facility by using different operating modes of PASV: PASVNP, PASVPP, PASVLIA and $\Delta \mathrm{I} / \Delta \mathrm{t}$. The peak potential was measured at $1010-1140 \mathrm{mV}$. All results for pure $\mathrm{Se}(\mathrm{IV})$ were obtained using calibration curves and all results for pharmaceuticals were obtained using the method of standard additions.

\section{RESULTS AND DISCUSSION}

Voltammetric behaviour: The voltammograms (in the optimal conditions: composition of modified electrode, concentration $\mathrm{HClO}_{4}$, accumulation potential and accumulation time $^{8}$ ) using a methylene blue-nafion modified gold electrode by different operating modes of pulse anodic stripping voltammetry (PASV): with PASVNP, PASVPP, PASVLIA and $\Delta \mathrm{I} / \Delta \mathrm{t}$ were shoed in Fig. 1 . The peak potential was measured at 1000-1010, 1030-1040, 1130-1140 and 1030-1060 mV for operating modes PASVNP, PASVPP, PASVLIA and $\Delta \mathrm{I} / \Delta \mathrm{t}$, respectively. The optimum parameters established for studied different operating modes of pulse anodic stripping voltammetry showed in Table-1.

Calibration curves: Calibration curves for the determination of Se(IV) using a methylene blue-nafion modified gold electrode by different operating modes of PASV were studied. The peak current (Ip) was proportional to the concentration of $\mathrm{Se}(\mathrm{IV})$ over the ranges 7.896-78.96 $\mathrm{ng} \mathrm{mL}^{-1},(\mathrm{y}=102.7 \mathrm{x}+$ $\left.0.820, \mathrm{R}^{2}=0.999\right), 23.688-118.44 \mathrm{ng} \mathrm{mL}^{-1},(\mathrm{y}=8.081 \mathrm{x}+$ $\left.3.025, \mathrm{R}^{2}=0.993\right), 23.688-118.44 \mathrm{ng} \mathrm{mL}^{-1},(\mathrm{y}=208.1 \mathrm{x}+$ $\left.10.20, \mathrm{R}^{2}=0.997\right)$ and $0.7896-78.96 \mathrm{ng} \mathrm{mL}^{-1},(\mathrm{y}=145.8 \mathrm{x}+$ $0.645, \mathrm{R}^{2}=0.999 ; \mathrm{y}: \mathrm{I}_{\mathrm{p}}, \mathrm{nA}$ and $\left.\mathrm{x}: \mathrm{C}_{\mathrm{Se}(\mathrm{IV})}, \mathrm{ng} \mathrm{mL}^{-1}\right)$ using PASVNP, PASVPP, PASVLIA and $\Delta \mathrm{I} / \Delta \mathrm{t}$ respectively.

Analytical results: Determination of $\mathrm{Se}(\mathrm{IV})$ on the methylene blue-nafion modified electrode by different operating modes of PASV using analytical curves, $\mathrm{I}_{\mathrm{p}}=\mathrm{f}\left(\mathrm{C}_{\mathrm{Se}(\mathrm{IV})}\right)$, showed that the sensitivity increase according to the following operating modes: PASVPP, PASVLIA,PASVNP and $\Delta \mathrm{I} / \Delta \mathrm{t}$, respectively and the accuracy increase according to the following operating modes: PASVPP, PASVLIA, $\Delta \mathrm{I} / \Delta \mathrm{t}$ and PASVNP, respectively (Table-2). Limit of detection and limit of quantitation for the determination of Se(IV) by different operating modes were applied. The volumes of limit of detection were as the followas : $0.89,3.5,3.4$ and $0.11 \mathrm{ng} \mathrm{mL}^{-1}$ and the volumes of limit of quantitation were as the followas : 2.7 , 10.6, 10.4 and $0.32 \mathrm{ng} \mathrm{mL}^{-1}$ using PASVNP, PASVPP, PASVLIA and $\Delta \mathrm{I} / \Delta \mathrm{t}$, respectively.

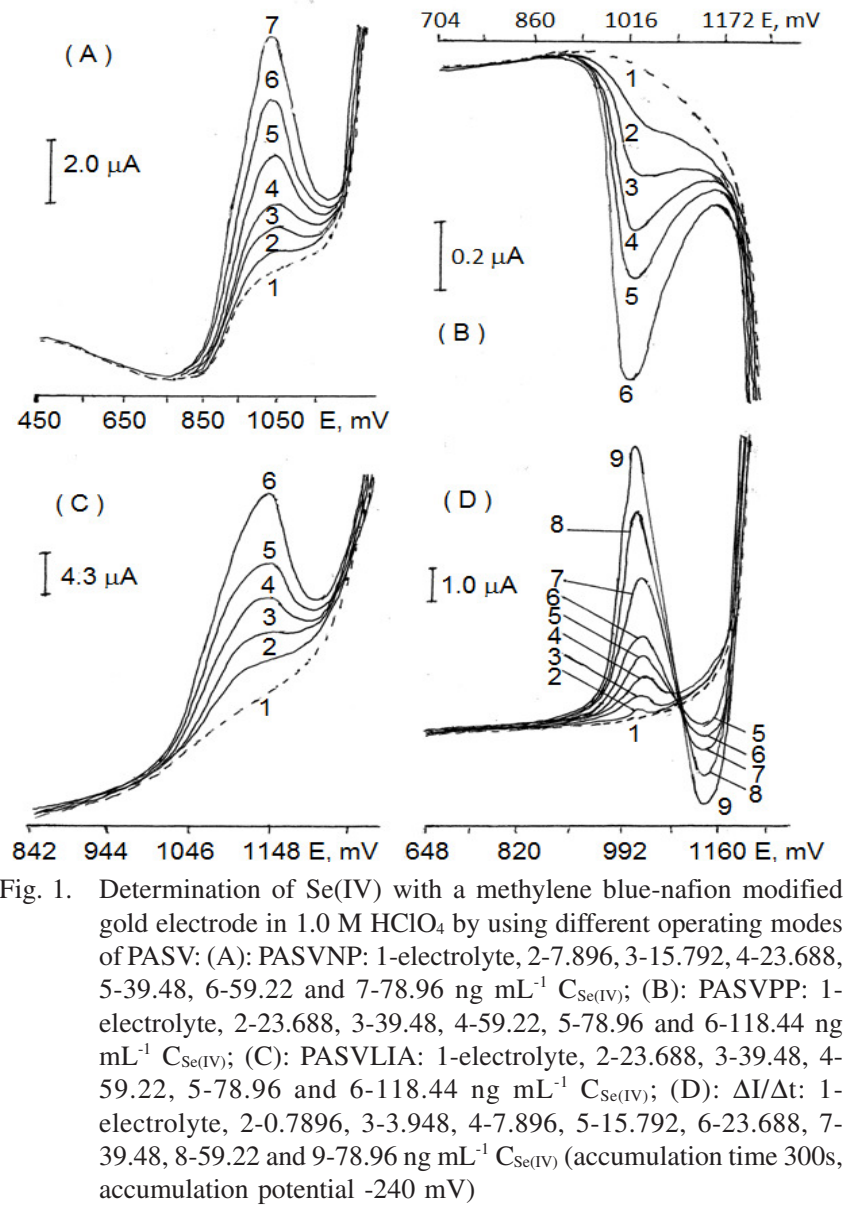

Applications: Many applications for the determination of Se(IV) in some Syrian pharmaceutical preparations with a methylene blue-nafion modified gold electrode in $1.0 \mathrm{M} \mathrm{HClO}_{4}$ by using different operating modes of pulse anodic stripping voltammetry: with PASVNP, PASVPP, PASVLIA and $\Delta \mathrm{I} / \Delta \mathrm{t}$ were proposed. Regression equations and correlation coefficients were included in Table-3. Standard additions curves for determination of selenium in different Syrian pharmaceutical preparations were used. The standard additions curves of cenyite silver by using mentioned operating modes were showed in Fig. 2, as an example. It was found that the pulse anodic stripping voltammetry with constant amplitude of negative polarity (PASVNP) method is the most accurate compared to the other studied methods. The amount of selenium in the sample $(\mathrm{m})$ calculated from the following relationship: $\mathrm{m}=$ h.m', where: $\mathrm{m}^{\prime}$ is the amount of selenium in tablet ( $\mu \mathrm{g} / \mathrm{tab}$.) calculated from the standard additions curve according to the following regression equation: $\mathrm{y}=\mathrm{a} \cdot \mathrm{x}+\mathrm{b}$; when $\mathrm{y}=0$ is $\mathrm{m}^{\prime}=$ $\mathrm{x}=\mathrm{b} / \mathrm{a}=$ intercept/slope and $\mathrm{h}$ is (the stated amount of selenium 
TABLE-1

OPTIMUM PARAMETERS ESTABLISHED FOR DETERMINATION OF Se (IV) WITH A METHYLENE BLUE-NAFION MODIFIED GOLD ELECTRODE IN $1.0 \mathrm{M} \mathrm{HCLO}_{4}$ BY USING DIFFERENT OPERATING MODES OF PULSE ANODIC STRIPPING VOLTAMMETRY

\begin{tabular}{|c|c|c|c|c|}
\hline \multirow{2}{*}{ Parameters } & \multicolumn{4}{|c|}{ Operating modes } \\
\hline & PASVNP & PASVPP & PASVLIA & $\Delta \mathrm{I} / \Delta \mathrm{t}$ \\
\hline Accumulation (deposition) time & \multicolumn{4}{|c|}{$300 \mathrm{~s}$} \\
\hline Accumulation potential & \multicolumn{4}{|c|}{$-240 \mathrm{mV}$} \\
\hline Supporting electrolyte & \multicolumn{4}{|c|}{$1.0 \mathrm{M} \mathrm{HClO}_{4}$} \\
\hline Indicator electrode & \multicolumn{4}{|c|}{ Rotating disk gold electrode (RDGE) } \\
\hline Modified electrode composition & \multicolumn{4}{|c|}{$1.2 \mathrm{mg} \mathrm{mL}^{-1}$ methylene blue and nafion $2 \%, \mathrm{v} / \mathrm{v}$ ethanol } \\
\hline Waiting time & \multicolumn{4}{|c|}{$5 \mathrm{~s}$} \\
\hline Initial potential & \multicolumn{4}{|c|}{$0.0 \mathrm{mV}$} \\
\hline Final potential & \multicolumn{4}{|c|}{$+1250 \mathrm{mV}$} \\
\hline Pulse duration & \multicolumn{4}{|c|}{$20 \mathrm{~ms}$} \\
\hline Scan rate & \multicolumn{4}{|c|}{$10 \mathrm{mV} / \mathrm{s}$} \\
\hline Stirring speed & \multicolumn{4}{|c|}{$1000 \mathrm{rpm}$} \\
\hline Temperature of solution & \multicolumn{4}{|c|}{$25 \pm 0.5^{\circ} \mathrm{C}$} \\
\hline Peak Potential (mV) & $1000-1010$ & $1030-1040$ & $1130-1140$ & $1030-1060$ \\
\hline LOD (3.3SD), ng mL - $^{-1}$ & 0.89 & 3.5 & 3.4 & 0.11 \\
\hline LOQ (10SD), ng mL ${ }^{-1}$ & 2.7 & 10.6 & 10.4 & 0.32 \\
\hline Linearity range, $\mathrm{ng} \mathrm{mL}^{-1}$ & 7.896-78.96 & 23.688-118.44 & $23.688-118.44$ & $0.7896-78.96$ \\
\hline \multicolumn{5}{|l|}{ Regression equation: } \\
\hline Slope & 102.7 & 8.081 & 208.1 & 145.8 \\
\hline Intercept & 0.82 & 3.025 & 10.20 & 0.645 \\
\hline Correlation coefficient $\left(\mathrm{R}^{2}\right)$ & 0.999 & 0.993 & 0.997 & 0.999 \\
\hline $\operatorname{RSD}(\%)$ & 3.4 & 4.5 & 4.4 & 4.2 \\
\hline
\end{tabular}

TABLE-2

DETERMINATION OF Se (IV) WITH A METHYLENE BLUE-NAFION MODIFIED GOLD ELECTRODE IN $1.0 \mathrm{M} \mathrm{HCIO}_{4}$ BY USING DIFFERENT OPERATING MODES OF PULSE ANODIC STRIPPING VOLTAMMETRY (ACCUMULATION TIME $300 \mathrm{~s}$, ACCUMULATION POTENTIAL - $240 \mathrm{mV}$ )

\begin{tabular}{|c|c|c|c|c|c|c|}
\hline Operating modes & $\begin{array}{l}\mathrm{x}_{\mathrm{i}}, \mathrm{ng} \mathrm{mL}^{-1} \\
\text { (taken) }\end{array}$ & $\begin{array}{l}\overline{\mathrm{X}} *, \mathrm{ng} \mathrm{mL}^{-1} \\
\text { (found) }\end{array}$ & $\mathrm{SD}, \mathrm{ng} \mathrm{mL}^{-1}$ & $\frac{\mathrm{SD}}{\sqrt{\mathrm{n}}}, \mathrm{ng} \mathrm{mL}^{-1}$ & $\overline{\mathrm{x}} \pm \frac{\mathrm{t} \cdot \mathrm{SD}}{\sqrt{\mathrm{n}}} \mathrm{ng} \mathrm{mL} \mathrm{L}^{-1}$ & $\operatorname{RSD}(\%)$ \\
\hline \multirow{10}{*}{$\Delta \mathrm{I} / \Delta \mathrm{t}$} & 0.7896 & 0.782 & 0.032 & 0.014 & $0.782 \pm 0.040$ & 4.2 \\
\hline & 1.5792 & 1.595 & 0.065 & 0.029 & $1.595 \pm 0.081$ & 4.1 \\
\hline & 3.1584 & 3.158 & 0.13 & 0.059 & $3.158 \pm 0.163$ & 3.9 \\
\hline & 3.948 & 3.948 & 0.15 & 0.067 & $3.948 \pm 0.186$ & 3.8 \\
\hline & 7.896 & 7.975 & 0.28 & 0.125 & $7.975 \pm 0.348$ & 3.5 \\
\hline & 15.792 & 15.713 & 0.52 & 0.232 & $15.713 \pm 0.645$ & 3.3 \\
\hline & 23.688 & 23.688 & 0.76 & 0.340 & $23.688 \pm 0.943$ & 3.2 \\
\hline & 39.48 & 39.48 & 1.18 & 0.528 & $39.48 \pm 1.465$ & 3.0 \\
\hline & 59.22 & 54.96 & 1.50 & 0.671 & $54.96 \pm 1.862$ & 2.7 \\
\hline & 78.96 & 79.12 & 1.97 & 0.881 & $79.12 \pm 2.446$ & 2.5 \\
\hline \multirow{6}{*}{ PASVNP } & 7.896 & 7.875 & 0.27 & 0.121 & $7.875 \pm 0.335$ & 3.4 \\
\hline & 15.792 & 15.793 & 0.50 & 0.224 & $15.793 \pm 0.621$ & 3.1 \\
\hline & 23.688 & 23.684 & 0.71 & 0.317 & $23.684 \pm 0.881$ & 3.0 \\
\hline & 39.48 & 39.48 & 1.11 & 0.496 & $39.48 \pm 1.378$ & 2.8 \\
\hline & 59.22 & 54.98 & 1.37 & 0.613 & $54.98 \pm 1.701$ & 2.5 \\
\hline & 78.96 & 78.83 & 1.73 & 0.774 & $78.83 \pm 2.148$ & 2.2 \\
\hline \multirow{8}{*}{ PASVLIA } & 23.688 & 23.680 & 1.04 & 0.465 & $23.680 \pm 1.291$ & 4.4 \\
\hline & 31.584 & 31.862 & 1.37 & 0.613 & $31.862 \pm 1.701$ & 4.3 \\
\hline & 39.48 & 39.35 & 1.65 & 0.738 & $39.35 \pm 2.048$ & 4.2 \\
\hline & 47.376 & 47.375 & 1.94 & 0.868 & $47.375 \pm 2.408$ & 4.1 \\
\hline & 59.22 & 59.06 & 2.42 & 1.08 & $59.06 \pm 3.004$ & 4.1 \\
\hline & 67.116 & 67.193 & 2.69 & 1.20 & $67.193 \pm 3.340$ & 4.0 \\
\hline & 78.96 & 78.87 & 3.07 & 1.37 & $78.87 \pm 3.811$ & 3.9 \\
\hline & 118.44 & 118.40 & 4.38 & 1.96 & $118.40 \pm 5.438$ & 3.7 \\
\hline \multirow{8}{*}{ PASVPP } & 23.688 & 23.687 & 1.06 & 0.474 & $23.687 \pm 1.316$ & 4.5 \\
\hline & 39.48 & 39.42 & 1.93 & 0.863 & $39.42 \pm 2.396$ & 4.9 \\
\hline & 47.376 & 47.375 & 2.23 & 0.997 & $47.375 \pm 2.768$ & 4.7 \\
\hline & 59.22 & 59.18 & 2.72 & 1.22 & $59.18 \pm 3.377$ & 4.6 \\
\hline & 67.116 & 67.23 & 2.96 & 1.32 & $67.23 \pm 3.675$ & 4.4 \\
\hline & 78.96 & 78.99 & 3.40 & 1.52 & $78.99 \pm 4.221$ & 4.3 \\
\hline & 98.70 & 98.53 & 4.14 & 1.85 & $98.53 \pm 5.140$ & 4.2 \\
\hline & 118.44 & 118.52 & 4.86 & 2.17 & $118.52 \pm 6.034$ & 4.1 \\
\hline
\end{tabular}




\begin{tabular}{|c|c|c|c|c|}
\hline \multicolumn{5}{|c|}{$\begin{array}{c}\text { TABLE } 3 \\
\text { REGRESSION EQUATIONS AND CORRELATION COEFFICIENTS FOR THE DETERMINATION OF Se(IV) } \\
\text { IN SOME SYRIAN PHARMACEUTICAL PREPARATIONS USING STANDARD ADDITIONS METHOD } \\
\text { BY USING DIFFERENT OPERATING MODES OF PASV (m' = INTERCEPT/SLOPE) }\end{array}$} \\
\hline \multirow{2}{*}{$\begin{array}{c}\text { Pharmaceutical } \\
\text { preparations }\end{array}$} & \multicolumn{4}{|c|}{ Operating modes } \\
\hline & PASVNP & PASVPP & PASVLIA & $\Delta \mathrm{I} / \Delta \mathrm{t}$ \\
\hline Cenyite Silver & $y=102.7 x+2698$ & $y=8.08 x+213$ & $y=208.3 x+5470$ & $y=145.8 x+3843$ \\
\hline $20 \mu \mathrm{g} / \mathrm{tab}$ & $R^{2}=0.999$ & $\mathrm{R}^{2}=0.993$ & $R^{2}=0.997$ & $R^{2}=0.999$ \\
\hline $\begin{array}{c}\text { Cenvite } \\
25 \mu \mathrm{g} / \mathrm{tab} \text {. }\end{array}$ & $\begin{array}{c}\mathrm{m}_{\mathrm{Se}(\mathrm{IV}) / \mathrm{tbl} .}=0.8 \mathrm{~m}^{\prime} \\
\mathrm{y}=102.6 \mathrm{x}+2642 \\
\mathrm{R}^{2}=0.999\end{array}$ & $\begin{array}{c}\mathrm{m}_{\mathrm{Se}(\mathrm{IV}) / \mathrm{tbl} .}=0.8 \mathrm{~m}^{\prime} \\
\mathrm{y}=8.10 \mathrm{x}+210 \\
\mathrm{R}^{2}=0.993\end{array}$ & $\begin{array}{c}\mathrm{m}_{\mathrm{Se}(\mathrm{IV}) / \mathrm{tbl}}=0.8 \mathrm{~m}^{\prime} \\
\mathrm{y}=202.3 \mathrm{x}+5365 \\
\mathrm{R}^{2}=0.997\end{array}$ & $\begin{array}{c}\mathrm{m}_{\mathrm{Se}(\mathrm{IV}) / \mathrm{tbl} .}=0.8 \mathrm{~m}^{\prime} \\
\mathrm{y}=146.0 \mathrm{x}+3755 \\
\mathrm{R}^{2}=0.999\end{array}$ \\
\hline $\begin{array}{l}\text { Ophtavite } \\
40 \mu \mathrm{g} / \mathrm{tab} \text {. }\end{array}$ & $\begin{array}{c}\mathrm{m}_{\mathrm{Se}(\mathrm{IV}) / \mathrm{tbl} .}=\mathrm{m}^{\prime} \\
\mathrm{y}=102.7 \mathrm{x}+2722 \\
\mathrm{R}^{2}=0.999\end{array}$ & $\begin{array}{c}\mathrm{m}_{\mathrm{Se}(\mathrm{IV}) / \mathrm{tbl} .}=\mathrm{m}^{\prime} \\
\mathrm{y}=8.09 \mathrm{x}+216 \\
\mathrm{R}^{2}=0.993\end{array}$ & $\begin{array}{c}\mathrm{m}_{\mathrm{Se}(\mathrm{IV}) / \mathrm{bl} .}=\mathrm{m}^{\prime} \\
\mathrm{y}=208.4 \mathrm{x}+5568 \\
\mathrm{R}^{2}=0.997\end{array}$ & $\begin{array}{c}\mathrm{m}_{\mathrm{Se}(\mathrm{IV}) \mathrm{tbl} .}=\mathrm{m}^{\prime} \\
\mathrm{y}=145.8 \mathrm{x}+3841 \\
\mathrm{R}^{2}=0.999\end{array}$ \\
\hline $\begin{array}{l}\text { Supratech } \\
55 \mu \mathrm{g} / \mathrm{tab} \text {. }\end{array}$ & $\begin{array}{c}\mathrm{m}_{\mathrm{Se}(\mathrm{IV}) / \mathrm{tbl} .}=1.6 \mathrm{~m}^{\prime} \\
\mathrm{y}=103.0 \mathrm{x}+2755 \\
\mathrm{R}^{2}=0.999\end{array}$ & $\begin{array}{c}\mathrm{m}_{\mathrm{Se}(\mathrm{IV}) / \mathrm{tbl} .}=1.6 \mathrm{~m}^{\prime} \\
\mathrm{y}=8.08 \mathrm{x}+216 \\
\mathrm{R}^{2}=0.993\end{array}$ & $\begin{array}{c}\mathrm{m}_{\mathrm{Se}(\mathrm{IV}) / \mathrm{tbl} .}=1.6 \mathrm{~m}^{\prime} \\
\mathrm{y}=208.2 \mathrm{x}+5544 \\
\mathrm{R}^{2}=0.997\end{array}$ & $\begin{array}{c}\mathrm{m}_{\mathrm{Se}(\mathrm{IV}) / \mathrm{tbl} .}=1.6 \mathrm{~m}^{\prime} \\
\mathrm{y}=145.7 \mathrm{x}+3864 \\
\mathrm{R}^{2}=0.999\end{array}$ \\
\hline $\begin{array}{l}\text { Adavit Silver } \\
105 \mu \mathrm{g} / \mathrm{tab}\end{array}$ & $\begin{array}{l}\mathrm{m}_{\mathrm{Se}(\mathrm{IV}) / \mathrm{tbl}}=2.2 \mathrm{~m}^{\prime} \\
\mathrm{y}=102.8 \mathrm{x}+2759 \\
\mathrm{R}^{2}=0.999 \\
\mathrm{~m}_{\mathrm{Se}(\mathrm{IV} / \mathrm{tbl} .}=4.2 \mathrm{~m}^{\prime}\end{array}$ & $\begin{array}{c}\mathrm{m}_{\mathrm{Se}(\mathrm{IV}) / \mathrm{tbl}}=2.2 \mathrm{~m}^{\prime} \\
\mathrm{y}=8.09 \mathrm{x}+218 \\
\mathrm{R}^{2}=0.993 \\
\mathrm{~m}_{\mathrm{Se}(\mathrm{IV}) / \mathrm{tbl}}=4.2 \mathrm{~m}^{\prime}\end{array}$ & $\begin{array}{c}\mathrm{m}_{\mathrm{Se}(\mathrm{IV}) / \mathrm{tbl} .}=2.2 \mathrm{~m} \\
\mathrm{y}=2008.1 \mathrm{x}+5590 \\
\mathrm{R}^{2}=0.997 \\
\mathrm{~m}_{\mathrm{Se}(\mathrm{IV} / \mathrm{tbl} .}=4.2 \mathrm{~m}\end{array}$ & $\begin{array}{c}\mathrm{m}_{\mathrm{Se}(\mathrm{IV}) / \mathrm{tbl}}=2.2 \mathrm{~m}^{\prime} \\
\mathrm{y}=146.0 \mathrm{x}+3723 \\
\mathrm{R}^{2}=0.999 \\
\mathrm{~m}_{\mathrm{Se}(\mathrm{IV}) / \mathrm{tbl}}=4.2 \mathrm{~m}^{\prime}\end{array}$ \\
\hline
\end{tabular}

in the sample, $\mu \mathrm{g} / \mathrm{tab}.) / 25$. The results of quantitative analysis for $\mathrm{Se}(\mathrm{IV})$ in the pharmaceutical preparations using PASVNP method were calculated by the standard additions method, (Table-4).
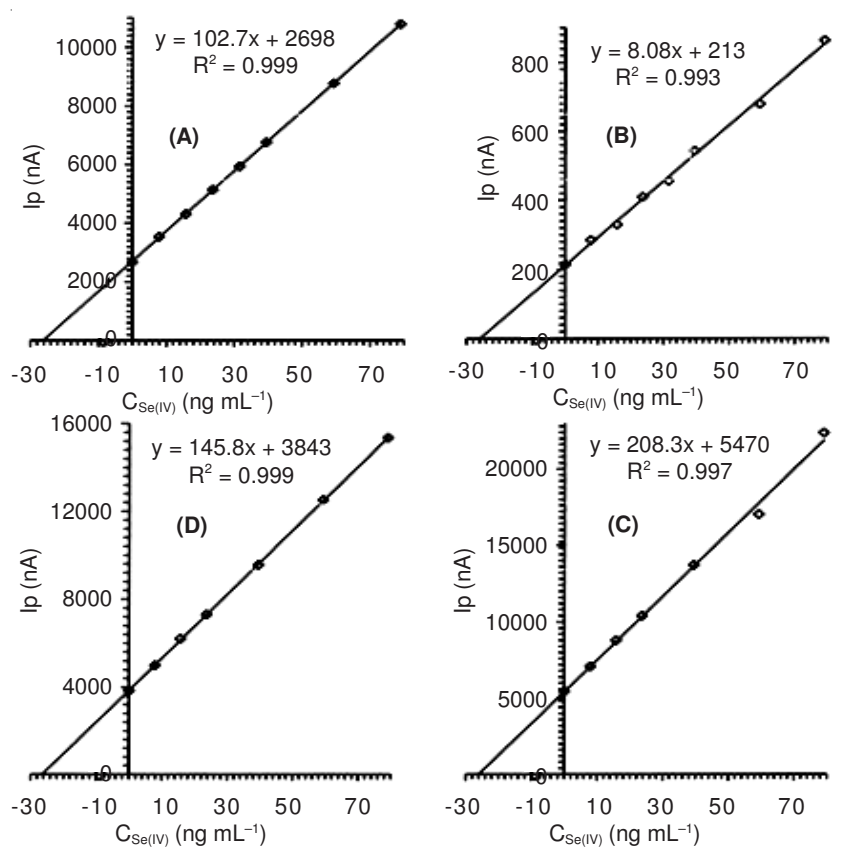

Fig. 2. $I_{p}=f\left(C_{S e(I V)}\right)$ for determination of Se (IV) in Syrian pharmaceutical preparations (cenyite silver) with a methylene blue-nafion modified gold electrode by using different operating modes of pulse anodic stripping voltammetry: (A) PASVNP; (B) PASVPP; (C) PASVLIA and (D) $\Delta \mathrm{I} / \Delta \mathrm{t}$ (accumulation time $300 \mathrm{~s}$, accumulation potential $-240 \mathrm{mV}$, y: $\mathrm{I}_{\mathrm{p}}, \mathrm{nA}$ and $\left.\mathrm{x}: \mathrm{C}_{\mathrm{Se}(\mathrm{IV})}, \mathrm{ng} \mathrm{mL}^{-1}\right)$

\section{Conclusion}

Determination of Se(IV) in Syrian pharmaceuticals with a methylene blue-nafion modified gold electrode by using different operating modes of PASV: with PASVNP, PASVPP, PASVLIA and $\Delta \mathrm{I} / \Delta \mathrm{t}$ was applied. Se(IV) was determined in an aqueous $\mathrm{HClO}_{4}$ medium $(1.0 \mathrm{M})$ at an accumulation potential of $-240 \mathrm{mV}$ and an accumulation time of $300 \mathrm{~s}$. The potential was scanned from 0.0 to $1250 \mathrm{mV}$ using auto-scan

\begin{tabular}{|c|c|c|c|c|}
\hline \multicolumn{5}{|c|}{$\begin{array}{c}\text { TABLE-4 } \\
\text { DETERMINATION OF Se(IV) IN SOME SYRIAN } \\
\text { PHARMACEUTICAL PREPARATIONS USING STANDARD } \\
\text { ADDITIONS METHOD BY USING PASVNP METHOD }\end{array}$} \\
\hline Commercial name & Contents & $\overline{\mathrm{x}} \mu \mathrm{g} / \mathrm{tab}$ & $\begin{array}{r}\text { RSD } \\
(\%) \\
\end{array}$ & $\begin{array}{c}\text { Recovery } \\
(\%)\end{array}$ \\
\hline $\begin{array}{l}\text { Cenyite Silver,Ctd.tab. } \\
\text { Pharmasyr Co. } \\
\text { Damascus-SYRIA }\end{array}$ & $\begin{array}{c}20 \\
\mu \mathrm{g} / \mathrm{tab}\end{array}$ & 21.01 & 3.6 & 105.05 \\
\hline $\begin{array}{l}\text { Cenvite, } \text { Ctd.tab. } \\
\text { Pharmasyr Co. } \\
\text { Damascus-SYRIA }\end{array}$ & $\begin{array}{c}25 \\
\mu \mathrm{g} / \mathrm{tab}\end{array}$ & 25.75 & 3.6 & 103.00 \\
\hline $\begin{array}{l}\text { Ophtavite, Ctd. tab. } \\
\text { Medipharm for } \\
\text { pharmaceutical industries } \\
\text { Damascus-SYRIA }\end{array}$ & $\begin{array}{c}40 \\
\mu \mathrm{g} / \mathrm{tab}\end{array}$ & 42.41 & 3.1 & 106.03 \\
\hline $\begin{array}{l}\text { Supratech, Ctd. tab. } \\
\text { MPI } \\
\text { Damascus-SYRIA }\end{array}$ & $\begin{array}{c}55 \\
\mu \mathrm{g} / \mathrm{tab}\end{array}$ & 58.85 & 3.3 & 107.00 \\
\hline $\begin{array}{l}\text { Adavit Silver, Ctd. tab. } \\
\text { Adamco co. } \\
\text { Damascus-SYRIA }\end{array}$ & $\begin{array}{c}105 \\
\mu \mathrm{g} / \mathrm{tab}\end{array}$ & 107.40 & 3.0 & 102.29 \\
\hline
\end{tabular}

facility. The peak potential was measured at 1000-1010, 10301040, 1130-1140 and 1030-1060 $\mathrm{mV}$ and the calibration graph for $\mathrm{Se}(\mathrm{IV})$ under optimized conditions was linear in the ranges 7.896-78.96, 23.688-118.44, 23.688-118.44 and 0.7896-78.96 $\mathrm{ng} \mathrm{mL} \mathrm{mL}^{-1}$ for operating modes (PASVNP), (PASVPP), (PASVLIA) and $(\Delta \mathrm{I} / \Delta \mathrm{t})$, respectively. RSD \% was less than 5 .

\section{REFERENCES}

1. M. Ashournia and A. Aliakbar, J. Hazard. Mater., 174, 788 (2010).

2. A.-I. Stoica, G.-R. Babaua, E.-E. Iorgulescu, D. Marinescu and G.-E. Baiulescu, J. Pharm. Biomed. Anal., 30, 1425 (2002).

3. M. Grabarczyk and M. Korolczuk, J. Hazard. Mater., 175, 1007 (2010).

4. M. Coulibaly, M.E. Ghanjaoui, A. Gonzálvez, M. de la Guardia and M. El-Rhazi, Arabian J. Chem., 1, 307 (2008).

5. N.K. Zaitsev, E.A. Osipova, D.M. Fedulov, E.A. Eremenko and A.G. Dedov, Zh. Anal. Khim., 61, 85 (2006).

6. A.U. Kulikov, J. Pharm. Biomed. Anal., 43, 1283 (2007).

7. N. Maleki, A. Safavi and M.M. Doroodmand, Talanta, 66, 858 (2005).

8. A.A. Ramadan, H. Mandil and A. Ozoun, Asian J. Chem., 23, 843 (2011).

9. A.A. Ramadan, H. Mandil and A. Ozoun, Asian J. Chem., 24, 391 (2012). 